\title{
THE FACTORS THAT INFLUENCE JOB SATISFACTION: A STUDY OF MINING COMPANIES
}

\author{
Irwan Usman \\ Ph.D scholar, Post Graduate School of Economics \\ Hasanuddin University \\ South Sulawesi, Indonesia \\ Haris Maupa \\ Professor of Economics, Post Graduate School of Economics \\ Hasanuddin University \\ South Sulawesi, Indonesia \\ Siti Haerani \\ Professor of Economics, Post Graduate School of Economics \\ Hasanuddin University \\ South Sulawesi, Indonesia \\ Muhammad Idrus Taba \\ Ph.D of Economics, Post Graduate School of Economics \\ Hasanuddin University \\ South Sulawesi, Indonesia \\ DOI: 10.31364/SCIRJ/v6.i11.2018.P1118579 \\ http://dx.doi.org/10.31364/SCIRJ/v6.i11.2018.P1118579
}

\begin{abstract}
This study aims to analyze the effect of recognition factors of competency certification that affect job satisfaction in mining companies. The design of this study is a survey to obtain and collect primary data so that it can explain the influence between variables. This research was conducted at several mining companies in the Eastern Indonesia Region. The study population was employees of three mining companies, then sampling systematically randomized. The analysis technique used is multiple linear regression analysis to explain the influence between variables. The results showed that the variables of education, professional, industry, and self-taught recognition had a significant effect on job satisfaction. The contribution of this study explains that the recognition adopted from the recognition theory has given a large degree of influence on emotions and positive attitudes for employees.
\end{abstract}

Index Terms - recognition of education, profession, industry, self-taught, and job satisfaction

\section{INTRODUCTION}

The development of knowledge in the field of human resource management is so rapid as a form of application and resolution of the complexity of problems that arise in organizations. Social interaction between organizational members has consequences for the emergence of problems such as recognition and self-concept. The role of recognition and self-concept is important for employees to realize effectiveness in the organization (Tessema et al. 2013; Amoatemaa \& Kyeremeh, 2016). The concept of recognition becomes clearer when it is associated with the parent theory (grand theory), as explained by Frederick Herzberg's Two-Factor theory which states that employees who get recognition from the organization will produce job satisfaction for employees, whereas in the view of The Work Psychodynamics Theory is recognition that expected by a subject that is largely symbolic. 
Competency certification for mining company employees as a form of preparation for Indonesia in the face of international labor competition in the mining industry. In general, employee competency in Indonesia is relatively low compared to foreign countries which have long applied certification for employees in the entire mining industry. Mining companies are companies that are traditionally difficult to enter by local workers, such as those experienced by large mining companies.

The study of Walt et al. (2016) shows that mining company employees do not experience job satisfaction and on the other hand they lack skills so that it has an impact on decreasing job satisfaction. The findings of Tshivhase \& Vilakazi (2018) state that managerial support in the form of recognition and others are the most important factors in increasing job satisfaction. Masia \& Pienaar (2011) explain that management can make the issue of job satisfaction a priority in the development of human resources.

\subsection{Recognition}

\section{LITERATURE REVIEW}

Chikungwa \& Chamisa (2013) stated that employees feel very satisfied and motivated through recognition of performance and achievement. These findings support Herzberg's motivation theory. Using incentives and giving the best rewards every year or every three months will stimulate performance. Recognition of employee competencies in the form of a reward management system will contribute greatly to achieving maximum performance (Güngör, 2011).

Various researches or studies that have explained the concept of relationships or the influence of rewards and recognition of employees on motivation and performance. Ndungu (2017) describes programs from recognition capable of contributing to the realization of the overall goals of the organization, thus impacting on the relationship between appreciation and recognition of employee performance. This is also reinforced by the findings of Amoatemaa \& Kyeremeh (2016), that many organizations today are increasingly utilizing employee recognition to motivate employees and achieve the ultimate goal of high performance and productivity.

The results of the research of Ijosiga \& Odubuker (2016) reveal that employee recognition and performance have a moderate correlation, but statistically have a significant effect. Bradler et al. (2011) conducted field experiment research, the results of his research showed that the recognition given by the company to all workers in a group only increased the subsequent performance with a low level. Conversely, recognition that is only given to the best employees in a group is proven to improve performance substantially. This result is relevant to the behavior of employees who have a preference for adjustments at the same time.

\subsection{Job satisfaction}

Job satisfaction as a form or positive emotional attitude as a result of work experience in the organization (Akafo \& Boateng, 2015). Akafo \& Boateng then explained that job satisfaction can be formed from the efforts of organizations to give recognition to employees who have competence. Danish \& Ali (2010) states that increasing employee job satisfaction is one of the main tasks of management, especially for employees who are experienced and have good performance. They are the most important resource among the resources that the organization has. Increased job satisfaction can be achieved by giving awards and recognition to these employees.

Interaction with fellow coworkers and superiors in the organization, following rules and policies, meeting performance standards, working conditions and other factors can influence job satisfaction or dissatisfaction in the organization. Coffey (2013) which states that there is a direct influence between rewards and recognition of job satisfaction and motivation. Tessema et al. (2013) also found results that acknowledgment, salary, and employment benefits have a significant effect on job satisfaction.

\section{RESEARCH METHODS}

The design of this study is a survey that takes samples from a population and uses a questionnaire as a basic data collection tool. This research is a study that explains the influence between variables or called explanatory research, namely research to find out and explain the influence between existing variables and proceed with testing hypotheses. This research was conducted at three mining companies in the Eastern Indonesia Region. The population in this study were 2,550 certified employees.

Determination of the number of samples using Slovin formula, sampling using systematic random sampling. This technique is done by collecting a list of names of employees and their supervisors from the three companies. The main data collection technique is the distribution of questionnaires to respondents, the questionnaire was distributed as much as 460 to employees. The variables of this study consisted of independent variables (recognition of education, professional recognition, industry recognition, and self-taught recognition) and the dependent variable was job satisfaction. The analysis technique in this study uses multiple linear regression analysis. 


\section{RESULTS AND DISCUSSION}

\section{Characteristics of Respondents}

The results of the analysis of the characteristics of the research respondents aimed to identify the unit of analysis in more detail. These results are illustrated in the following table.

Table 1. Characteristics of Respondents

\begin{tabular}{ccc}
\hline Characteristics & Criteria & Percentage (\%) \\
\hline Gender & Man & 86.0 \\
& Female & 14.0 \\
Age & $20-30$ & 23.5 \\
& $31-40$ & 55.0 \\
& $41-50$ & 10.5 \\
Education & $51-60$ & 11.0 \\
& High school & 31.0 \\
\multirow{2}{*}{ Working period } & Diploma & 20.5 \\
& Bachelor / Masters & 48.5 \\
& $<=5$ years & 21.5 \\
& $5-10$ years & 57.0 \\
& $11-15$ years & 15.5 \\
& $16-20$ years & 1.5 \\
\hline
\end{tabular}

The results of the respondent's description indicate that more men participated in this study. The mining industry is identical to the work of men who generally have an educational background, are struggling with heavy equipment, high work pressure. Men also can work in hot and cold weather. However, female employees also have roles and contributions that are no less important in the mining industry. Several divisions or job descriptions that are intended for women.

The age criteria of respondents indicate that the age range between 31 to 40 years is the group of respondents who are the most dominant in this study. Badan Pusat Statistik explains that the age range is the most productive age, this is because employees already have career paths and sufficient work experience, so that this category of employees has already been at the senior level or is the leader of a division.

Based on the latest education level, it appears that the number of high school educated employees is more in all mining companies in this study. The number of respondents in that category is as much as 30 percent. These results indicate that the majority of employees working in mining companies rely on technical skills or work on operational and technical aspects of the company. In general, they work in open fields or with higher work risks.

In the working period, it was found that the working period between 5 and 10 years dominated the study. This is a differentiator between permanent employees and contract employees, the long working period indicates that the employee has better experience, service, sense of responsibility, courage and care about the situation in the company. Employees who have a longer working period will have better skills, level of knowledge, and analytics than employees who have a short working period.

\section{Regression Statistics}

The results of this study found that there was a positive and significant effect of the recognition of education on job satisfaction. This is indicated by the second $t$ statistic value of 2.986 and the sig value. which is less than 5 percent. This shows that recognition of education has a positive and significant effect on job satisfaction. Variation in job satisfaction is explained by the education recognition variable of 0.289 or 28.9 percent as indicated by the value of $\mathrm{R}$ Square. The results of this study also explained that there was a positive and significant effect of professional recognition of job satisfaction. The variation in job satisfaction explained by professional recognition is around 0.288 or 28.8 percent as indicated by the value of $\mathrm{R}$ Square.

Industry recognition has a positive and significant influence on job satisfaction. The variation in job satisfaction explained by industry recognition is around 0.256 or 25.6 percent as shown in $\mathrm{R}$ square. Self-taught recognition has a positive and significant effect on job satisfaction. Variation in job satisfaction explained by variables Self-taught recognition of 0.249 or 24.9 percent as indicated by the value of R Square. The details of the regression output are shown in Table 2. Therefore, this study confirms that there are positive 
effects for recognition of education, professional recognition, industry recognition, and self-recognition in influencing employee job satisfaction in mining companies.

Table 2. Regression Output

\begin{tabular}{lccccc}
\hline & \multicolumn{2}{c}{ Un-standardized Coefficients } & & & \\
& Beta & \multicolumn{1}{c}{ Std. Error } & R Square & T & Sig. \\
\hline Constant & 0.129 & 0.408 & & 0.316 & 0.752 \\
Educational recognition & 0.263 & 0.088 & 0.289 & 2.986 & 0.004 \\
Professional recognition & 0.271 & 0.089 & 0.288 & 3.053 & 0.003 \\
Industry recognition & 0.223 & 0.097 & 0.256 & 2.300 & 0.024 \\
Self-taught recognition & 0.237 & 0.091 & 0.249 & 2.614 & 0.010 \\
\hline
\end{tabular}

Note: * Significant at 0.05

Recognition of competency certification recognition consisting of education, professional recognition, industry recognition, and self-taught recognition is an appreciation of the value of a person's ability to do something right or express knowledge of the existence or validity of one's ability to do something right. Recognition can also be meant that human social relations are formed by mutually acknowledging relationships between humans. Competence is a person's ability to do his work based on knowledge, abilities and skills. Competence is also part of individuals who can predict employee behavior and job satisfaction.

Certification emphasizes the competencies that must be possessed by a position such as mechanics, storeman, and others. The standard of competence of employees who hold a position can be measured. Certification emphasizes the competency of employees in the mining industry. Employees at mining companies, after going through an assessment, the employee can find out the level of competence in the mining industry.

If the competencies possessed by employees are good, the employee's job satisfaction will be better and vice versa. Competent employees usually have a relatively stable character, attitude, behavior, willingness and ability to work when facing situations at work. This will provide encouragement or motivation to employees to work on tasks assigned to them efficiently and effectively. Psychologically this will provide a meaningful work experience for employees. In the end all of these things will increase employee job satisfaction.

\section{CONCLUDING REMARKS}

The results showed that all independent variables had a positive and significant effect on job satisfaction. Improving the quality of education, professional, industry and self-taught recognition contributes to increased job satisfaction. Professional recognition variables have the dominant effect on job satisfaction with the lowest significance value. To improve, the company must identify and respond to employee needs, in the form of needs related to educational, professional, industrial, and self-taught recognition, which can have a positive emotional impact on employees.

\section{REFERENCES}

[1] Akafo, V., \& P.A. Boateng. (2015). Impact of Reward and Recognition on Job Satisfaction and Motivation. European Journal of Business and Management, Vol. 7, No. 24.

[2] Amoatemaa, A.S., \& D.D. Kyeremeh. (2016). Making Employee Recognition a Tool for Achieving Improved Performance: Implication for Ghanaian Universities. Journal of Education and Practice. Vol.7, No.34.

[3] Bradler, C., R. Dur., S. Neckermann., \& A. Non. (2011). Employee Recognition and Performance - A Field Experiment. Diakses pada https://pubsonline.informs.org.

[4] Chikungwa, T., \& S.F. Chamisa. (2013). An Evaluation of Recognition on Performance as a Motivator: A Case of Eastern Cape Higher Education Institution. Mediterranean Journal of Social Science, Vol. 4, No. 14.

[5] Coffey, Lisa. (2013). The relationship between reward management and recognition in the workplace. Dissertation. The National College of Ireland.

[6] Danish, R.Q., \& Ali Usman. (2010). Impact of Reward and Recognition on Job Satisfaction and Motivation: An Empirical Study from Pakistan. International Journal of Business and Management, Vol. 5, No. 2.

www.scirj.org

(C) 2018, Scientific Research Journal

http://dx.doi.org/10.31364/SCIRJ/v6.i10.2018.P1118579 
[7] Güngör, Pinar. (2011). The Relationship between Reward Management System and Employee Performance with the Mediating Role of Motivation: A Quantitative Study on Global Banks. Procedia-Social and Behavioral Sciences. Vol. 24, pp: 1510-1520.

[8] Ijosiga, A.W., \& E. P. Odubuker (2016). Recognition and staff performance in yumbe district local government, Uganda. European Journal of Management and Marketing Studies. Vol. 1, Issue 2.

[9] Masia, U., \& J. Pienaar (2011). Unravelling safety compliance in the mining industry: examining the role of work stress, job insecurity, satisfaction and commitment as antecedents. SA Journal of Industrial Psychology. Vol. 37, No. 1.

[10] Ndungu, D.N. (2017). The Effects of Rewards and Recognition on Employee Performance in Public Educational Institutions: A Case of Kenyatta University, Kenya. Global Journal of Management and Business Research: A Administration and Management, Volume 17 Issue 1

[11] Tessema, M.T., Kathryn J. Ready., \& Abel B. Embaye (2013). The Effects of Employee Recognition, Pay, and Benefits on Job Satisfaction: Cross Country Evidence. Journal of Business and Economics, ISSN 2155-7950. Volume 4, No. 1, pp. 1-12.

[12] Tshivhase, T., \& L. Vilakazi. (2018). Job Satisfaction: What factors in the Coal Mining Industry will lead to Higher Satisfaction?. International Journal of Management Science and Business Administration, Volume 4, Issue 6, pp: 17-25.

[13] Walt, Freda van der., M.E. Thasi., P. Jonck., \& C. Chipunza. (2016). Skills shortages and job satisfaction - Insights from the Gold-Mining sector of South Africa. African Journal of Business and Economic Research, Vol. 11, Issue 1, pp: 141-181. 